Look into region

\title{
Interdisciplinary Research at the Department of Archaeology, Philosophical Faculty, University of Hradec Králové
}

\author{
Richard Thér ${ }^{\mathrm{a}}$ \\ ${ }^{a}$ Department of Archaeology, Philosophical Faculty, University of Hradec Králové, Rokitanského 62, 50003 Hradec Králové, Czech Republic
}

\section{A RTICLE INFO}

\section{Article history:}

Received: $11^{\text {th }}$ July 2019

Accepted: $18^{\text {th }}$ August 2019

DOI: http://dx.doi.org/ 10.24916/iansa.2019.1.7

Key words:

experimental archaeology

technological analysis

automatic classification

University of Hradec Králové
A B S TRACT

The Philosophical Faculty of the University of Hradec Králové (FF UHK) has recently become copublisher of the IANSA journal. This represents an appropriate opportunity to look into the history of the interdisciplinary research at the Department of Archaeology of FF UHK. This article gives an overview of the research undertaken, mainly in the field of experimental archaeology and the study of ancient technologies. The overview demonstrates the natural links that exist between the Department's research focus and the profile of the journal.

\section{Beginnings of experimental research}

The beginnings of academic activity related to interdisciplinary research in archaeology in Hradec Králové are inseparably connected with Radomír Tichý. In 1993, he became an assistant for Ancient History and Antiquity at the Department of History, Faculty of Education, University of Hradec Králové (later the Institute of Historical Sciences at the University of Hradec Králové). In 1994, he founded there the University Centre of Experimental Archaeology and the regionally-active Society of Experimental Archaeology that brought together students and academics interested in experimental archaeology.

His first long-term experimental project was focused on the construction of a basic settlement unit of first farmers in central Europe. An early Neolithic longhouse was built in 1994 in a typical Neolithic settlement location positioned on a gentle southern slope at the confluence of two streams near Librantice, a few kilometres to the east of Hradec Králové (Figure 1). The house, as a basic structure of a Neolithic settlement unit, was accompanied by reconstructions of structures documented in the archaeological record -

*Corresponding author. E-mail: richard.ther@uhk.cz hearths, ovens, storage pits, a clay pit, a well - and also by theoretically-assumed components of the economic hinterland. All the structures were constructed using replicas of Neolithic artefacts. The experimental field trips focused on the building of the house and other structures, and subsequently on their use, and the replication of a whole spectrum of production activities as documented in an Early Neolithic context, was organised over several summer and winter campaigns (Tichý, 2000a). The project was terminated in 1998 due to changes in the land ownership. The same year, the experimentally-used area was excavated with the aim to interpret depositional processes on the site. The basic result of the excavation was that most of the lost or discarded artefacts and debris remained laying on the surface and did not enter the sunken features. Neolithic pottery, in particular, has a low potential to enter the deposits in sunken features as it soon disintegrates on the open surface (Tichý, 2001a).

\section{Centre of Experimental Archaeology and Archaeopark Všestary}

In 1996, R. Tichý, together with students of history, started to develop the Centre of Experimental Archaeology Všestary (CEA). The initial aim of the project was to create 


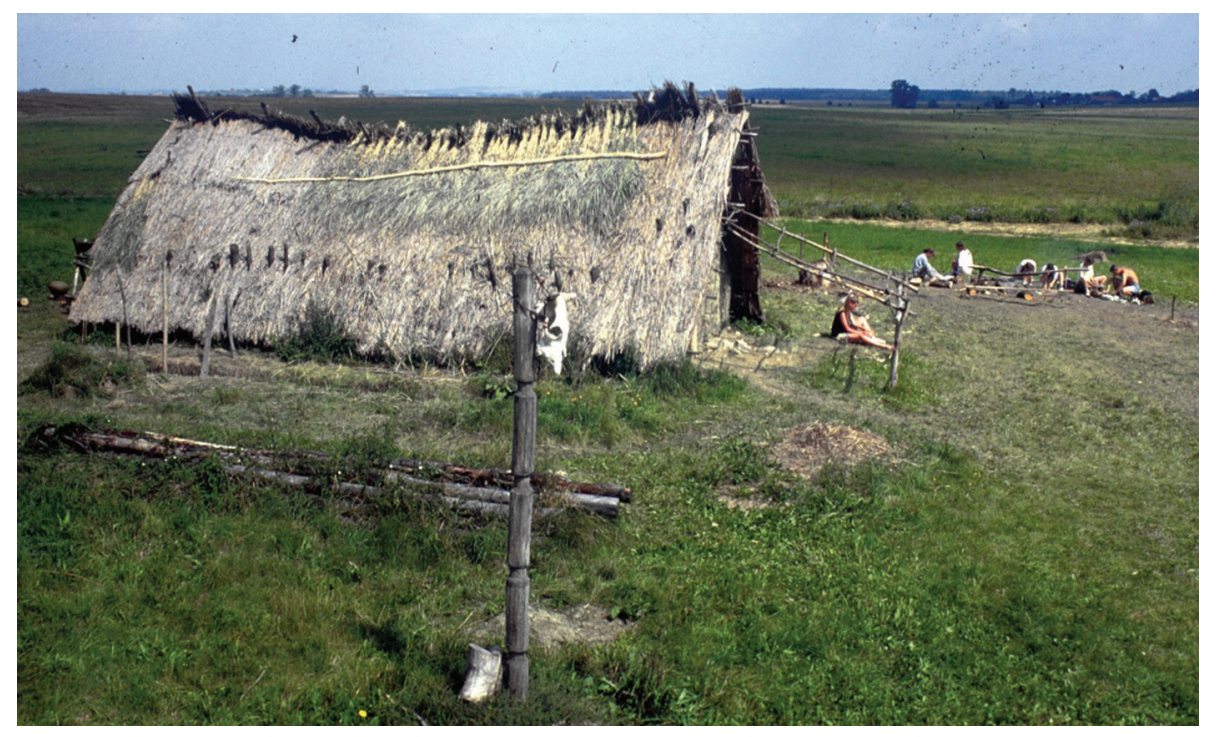

Figure 1. Experimental construction of the Neolithic long-house in Borek (photo by R. Tichý).

an environment suitable for field experiments. The model settlement unit comprised some basic types of settlement structures chosen to represent a variety of archaeological features typical for Eastern Bohemia. The main experimentally-constructed structures of the complex were two post-built houses based on Bronze Age finds and one semi-sunken dwelling based on evidence from the Hallstatt period. They were accompanied by other structures: a well, storage and clay pits, a variety of workshops, fields and a cemetery with various forms of burials (Figure 2; Thér and Tichý, 2000; 2002).

CEA also exploits the educational potential of the results of experimental archaeology. Since 2000, there has been an increased interest from primary and secondary schools to take part in the educational program "Touching Prehistory".
The programme is grounded on the fact that our knowledge of prehistory is based only on fragmentary material remains. The way of life in prehistory is distant to us and our idea of it is far from a complete picture. Teachers have only a few means or possibilities to create an image of prehistoric life that can be visualised by children. The program, therefore, uses the results of experimental archaeology to achieve a comprehensive perception of phenomena relating to prehistoric life in children's minds. Besides the experience with replicas of life-size structures built from adequate materials, the children and adults alike can themselves experience the craft technology of daily prehistoric life.

CEA also serves for the training of students of archaeology. There are two roles for university training at the CEA: 1) The students gain hands-on experience with the materials

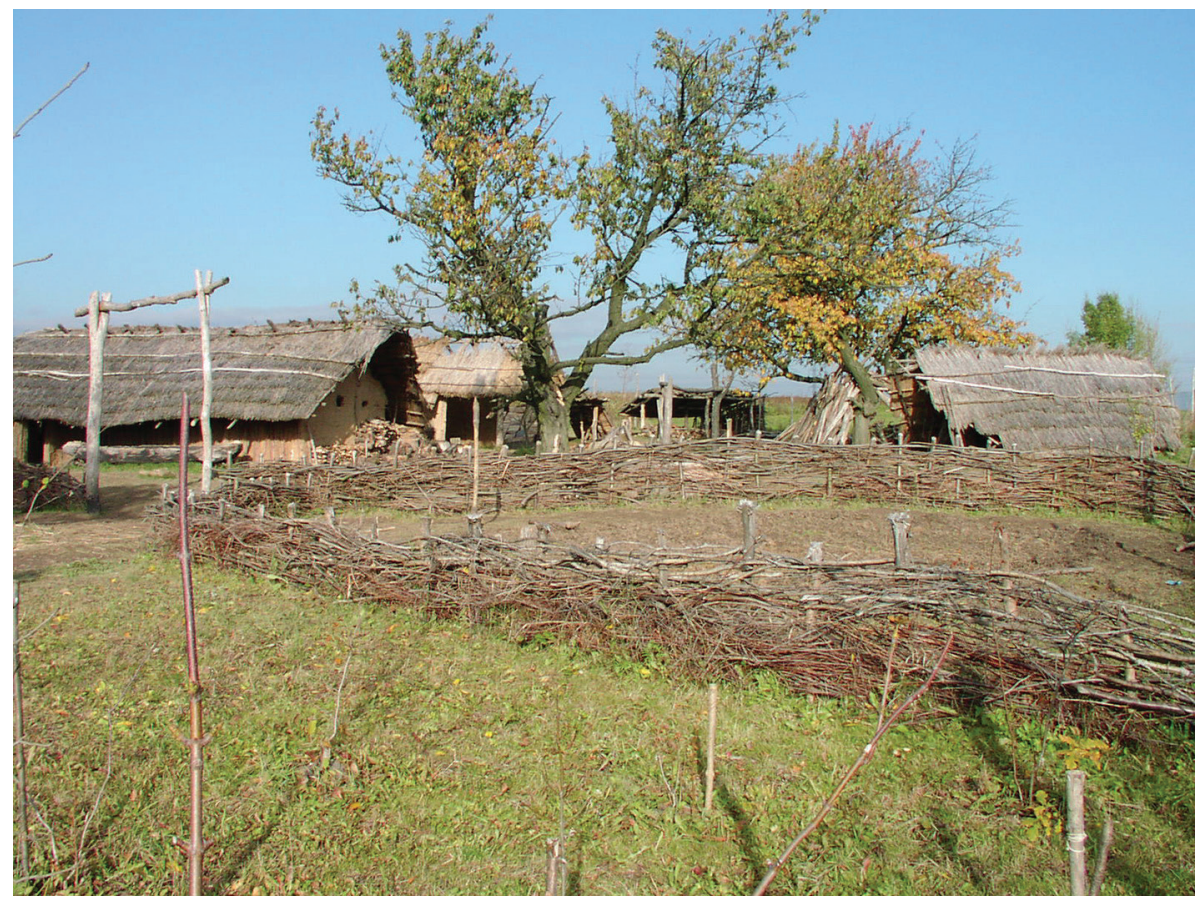

Figure 2. Centre of Experimental Archaeology V̌̌estary (photo by R. Thér). 
and techniques used in the archaeological periods studied and in the design of archaeological experiments in seminars supplementing the theoretical introduction to experimental archaeology; 2) They develop presentation skills for the dissemination of archaeological knowledge to the public during the practical training focused on visitor guiding and demonstrating the archaeologically-reconstructed processes.

With time, the presentation component of CEA's activities strengthened, which led to the transformation of the CEA into the Prehistoric Archaeopark Všestary, opened in 2013. The Archeopark represents a combination of both an open-air and indoor exhibition. The newly-constructed, three-floored building hosts a permanent exhibition that maps out the basic issues of archaeological inquiry with an emphasis on the interpretation of the archaeological record. The open-air part of the Archaeopark contains prehistoric buildings, workshops, clay pits, other types of settlement features, and a cemetery. An important part of the openair exhibition is a roofed model of an archaeological excavation. The permanent and temporary exhibitions are complemented by interactive programmes. Apart from the programmes for schools that follow the tradition of the programme "Touching Prehistory", there are also thematic weekends: so-called "Days of Living Archaeology". The theme of each event covers a specific topic, for example: burial rituals, harvest and processing of food, hunters and gatherers, Celtic craftsmanship, Romans on the fringes of the Imperium, archaeological excavation, etc. (Tichý, 2017).

\section{Monoxylon expeditions}

Another long-term and complex experimental project, Monoxylon expeditions, is focused on early sea navigation. Prior to the first maritime expedition, R. Tichý had had several years of experience with experimentally-reconstructed river logboats (Tichý, 2003). To date three expeditions in the Mediterranean have been carried out.
Monoxylon I expedition was undertaken in 1995. The aim of this first expedition was to test out the possibilities of sea navigation for the first farmers who ventured between the Middle East and mainland Greece. The objective of the first expedition was to verify the transport of people, crop and livestock by a dugout logboat. The boat of the first expedition was hypothetical because at the time of preparation for the expedition there had not been any findings of Neolithic dugout logboats in the Mediterranean. The boat was made out of a poplar tree using a "burning out" technique. In addition, replicas of Neolithic adzes and axes were tried out to shape the wood. The boat had originally been fitted with a mast and a boom sail. The results of the first expedition led to the conclusion that such type of sail is inappropriate for a logboat of such construction. The mast significantly reduced the vessel's stability in wavy conditions at sea because of the absence of a proper keel. The sail was only practical to use in a stern wind (coming directly from behind the boat), however, such conditions were rare during the voyage. The issue with the short-axis stability of the boat was solved by fixing a side float-log. Adding a side float took its toll though in slowing down the speed of the boat and in reducing the boat's manoeuvrability. This 6 metre-long boat with a side float-log travelled 290 kilometres at sea. The route started from the island of Samos and went through the chain of islands of Ikaria, Mykonos, Tinos, Andros and Evia up the coast of the Attica Peninsula, where it ended near the town of Nea Makri. The boat was proven seaworthy and able to transport a crew of nine alongside the additional load onboard (Tichý, 2001b; 2001c; 2016).

The Monoxylon II Expedition took place in late August and early September 1998. The main objective consisted in the practical testing of coastal navigation by logboat along the coast of Italy, France, Spain and Portugal. This expedition was a natural continuation of the first voyage to areas of occurrence of the Early Neolithic Cardium pottery culture. During their month at sea, the crew of the Monoxylon II paddled a distance of over 780 kilometres. The boat of Monoxylon II was inspired by the discovery of a Neolithic

Figure 3. Dugout logboat with sail on expedition Monoxylon III (photo by R. Thér).

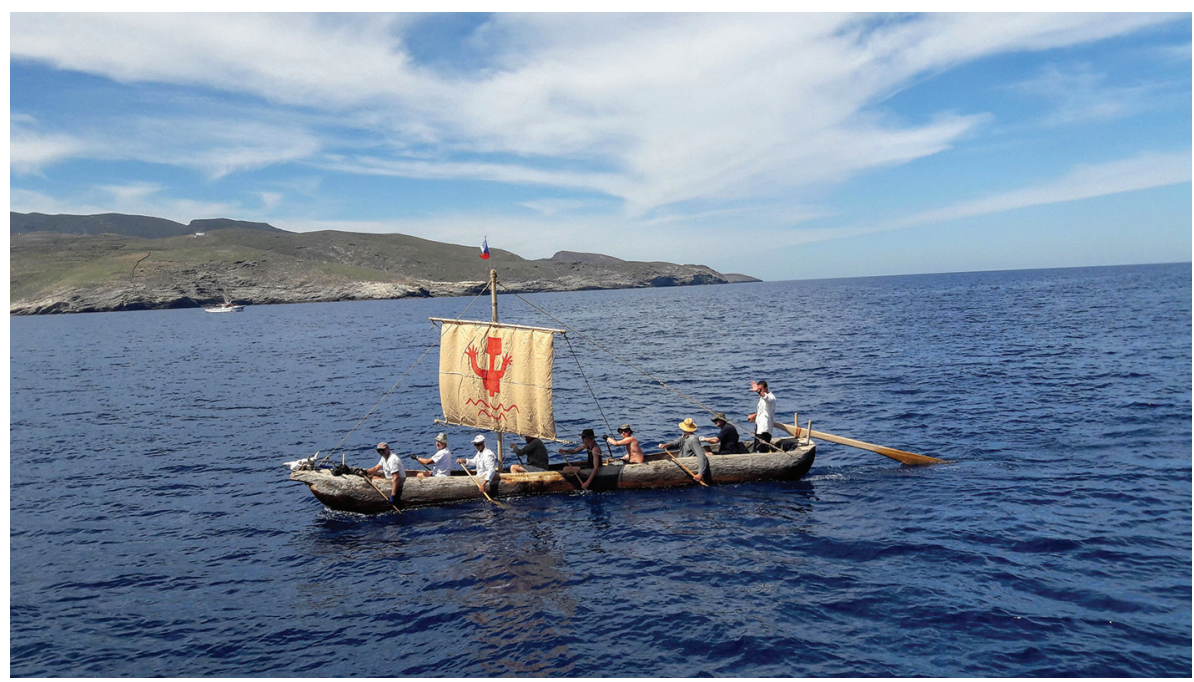


boat in Lake Bracciano (Italy) made of oak. Thanks to its reinforced bottom and the transverse "ribs" of the bottom (visible on the original), the monoxyl was very stable and reached an average speed of $5 \mathrm{~km} / \mathrm{h}$. A sail was not tested during this expedition (Tichý, 1999; 2000b; 2016).

The last expedition so far - Monoxylon III - took place in the spring and early summer of 2019. New archaeological evidence from Cyprus, Crete and other islands of the Aegean Sea allowed the reopening of questions related to the spread of agriculture and early maritime navigation. The latest expedition focused on further details of the use of primitive logboats as maritime vessels, especially the possible use of a simple sail, and also on the question of travel distances which could play a significant role in the way agricultural communities spread across other parts of the Mediterranean. These include the colonisation of Cyprus, islands of the Adriatic Sea, and the spread of obsidian between Sicily and the coast of Tunisia. The route of the expedition started from the Attica Peninsula, continued across the chain of islands to the Isle of Milos, which was a significant source of obsidian, and from there to the islands of Santorini and Crete. Monoxylon III used the boat of the second expedition, which was then modified to reflect more accurately the parameters of the original boat from Lake Bracciano. Also, some of the movable wood components found in the original logboat were taken into consideration and used in some hypothetical placements and with the tying of the sail. The expedition proved the capability of the boat to withstand the conditions prevalent in the Aegean Sea and the possibilities of using the simple sail efficiently (Figure 3 ).

\section{Study of pottery technology}

Another line of the research at the Department of Archaeology FF UHK, again grounded in the experimental and interdisciplinary approach, is the study of pottery technology. The methodology of identification of technological processes from archaeological evidence is systematically being developed. So far two lines of technological inquiry have been followed: identification of pottery firing processes and identification of pottery forming techniques.

Through a series of firing experiments we have ascertained that firing procedures does affect many of the characteristics of pottery and leaves archaeologically-testable traces. We studied selected parameters of the firing process, based on a large dataset of measured experimental pottery firings involving all basic types of pottery firing structures (hearths, clamps, kilns...) as evidenced or considered in archaeological research. The results showed that there is a significant difference between one-space and two-space firings. In onespace firings, the vessels are in direct contact with the fuel, while in two-space firings the vessels are separated from the fuel. Firing structures can be characterized by a specific range of thermal profiles based on the firing procedures that can be employed in these structures (Thér, 2014). The most important parameters usable for differentiation among firing processes are related to the dynamics of the firing. Consequently, determining the effects of the dynamics of the firing based on the properties of the ceramic products is a key step in the application of this approach to archaeological ceramics. That is why we have based our subsequent research on the hypothesis that procedures with the potential to develop fast heating and cooling rates with very short soaking times around the maximum temperature can cause a significant thermal gradient within the vessel wall. We experimentally determined the limits of the heating dynamics of the firing processes for two basic alternatives of pottery firing considered for the Early Neolithic in central Europebonfires and single-chamber kilns (Figures 4 and 5) - and analysed the thermal gradient within the walls of the fired pottery as the effect of these heating dynamics (Thér et al., 2018).

Another line of research related to the study of pottery firing has been a systematic study of the direct evidence of pottery firing structures. The main theme is the spread and development of two-chamber vertical kilns as one of the principal innovations in pottery technology that occurred during the Iron Age in central Europe. We explored the earliest evidence for such structures in the Hallstatt period (Mangel and Thér, 2014; Mangel, Thér and

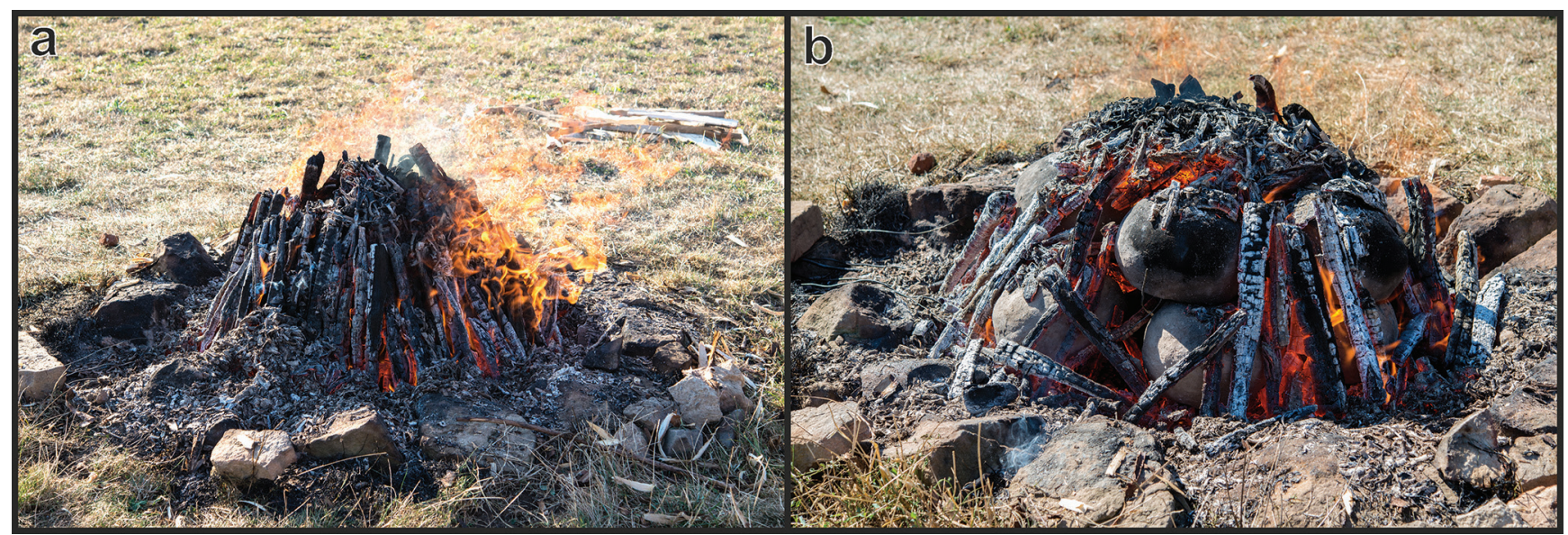

Figure 4. Experimental bonfire: a) firing at the moment of maximum temperature on the outer zone of the (pottery) load; b) pottery exposed during the cooling stage of the firing (photo by R. Thér). 


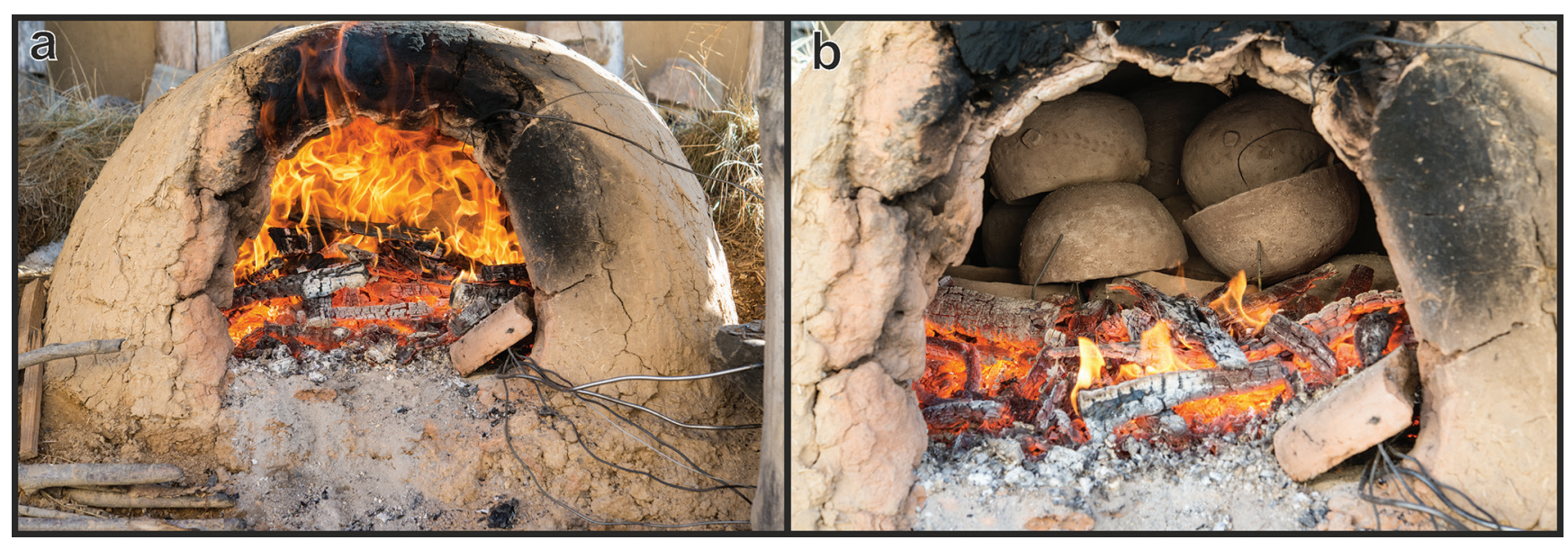

Figure 5. Experimental firing in a single-chamber kiln: a) firing at the moment of maximum temperature at the front of the load; b) pottery exposed during the cooling stage of the firing (photo by R. Thér).

Gregor, 2015) and comprehensively analysed the finds of the La Tène two-chamber vertical kilns in central Europe (Mangel and Thér, 2018).

The development of the methodology for the identification of pottery forming techniques was based on the relationship between forming techniques and the orientation of the components of ceramic materials. The alignment of inclusions and voids is usually characterized by qualitative categories or ordinal scales. We developed a quantitative approach. Measurement of the orientation refines the analysis of the preferred orientation by defining exact intervals of orientation variability for particular forming techniques and their combinations. Quantification of the alignment and orientation of inclusion yields objective criteria for interpretation the forming sequence employed. At first, an experimental collection of pottery manufactured using five basic forming techniques and combined techniques were analysed. The intervals of the alignment and orientation were then been proposed for the basic forming techniques (Thér, 2016). Subsequently, we focused on the differences in orientation among pottery-forming techniques utilising rotational movement. Apart from the comparison among the forming techniques, the effects of degree of transformation of the clay mass, shape of the vessel, velocity of rotation, as well as the individual experience of the potter on the orientation of particles in a wheel-thrown vessel wall were also evaluated. The results showed that wheel throwing can be differentiated from other applications of rotational movement in forming (Figure 6), but the characteristic orientation parameters are not independent of the context of the manufacture. They reflect the equilibrium established between the movements of the potter's hands, the technical parameters of the rotational device, properties of the clay and the shape of the vessel (Thér and Toms, 2016).

The proposed methodology was successfully applied to a study of the introduction of the potter's wheel in central
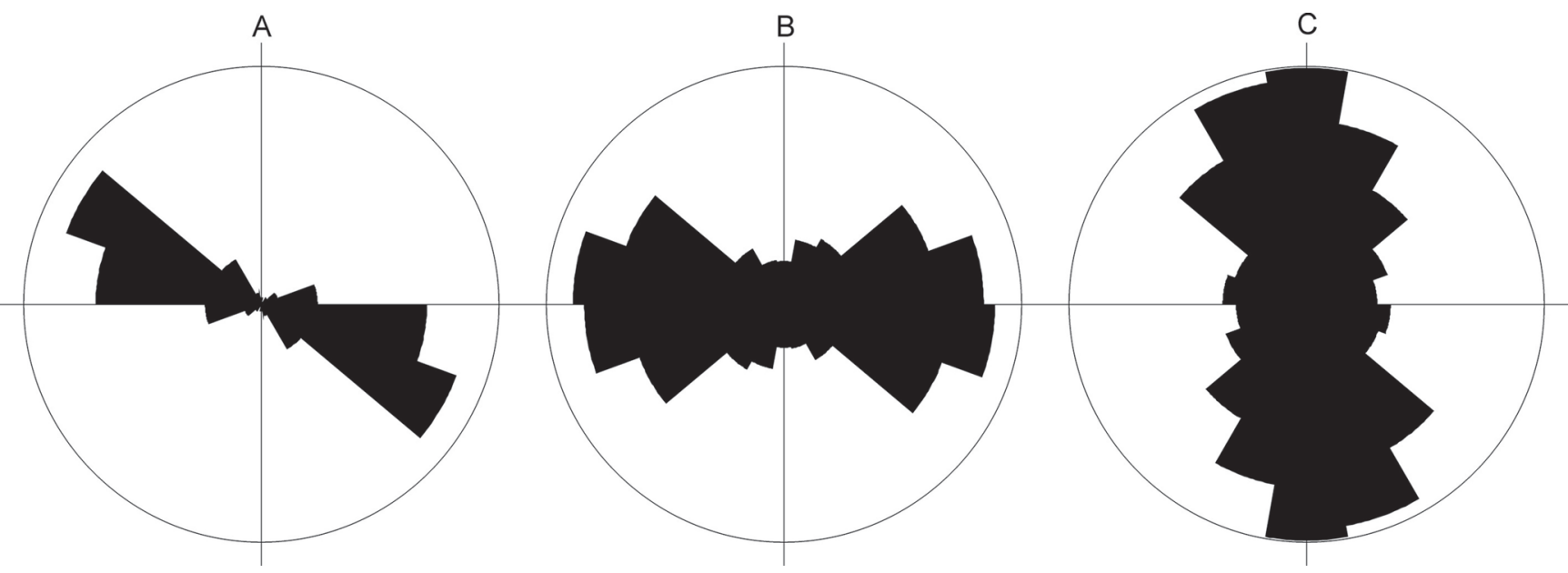

Figure 6. Differences in orientation of voids and particles in tangential section of the vessel wall among a wheel-thrown vessel (A), a wheel-shaped vessel with coiling as a primary forming technique (B), and a wheel-shaped vessel with pinching as a primary forming technique (C). The orientation is represented by rose diagrams showing the orientation of each detected inclusion or void in the sample (it is an alternative to the histogram for circular data). The wheelthrown vessel shows strong diagonal orientation corresponding with the direction of rotation (A). Horizontal orientation of the particles is typical for the wheel-shaped vessel combined with coiling. It reflects the orientation of the particles in the body of coils placed horizontally in the vessel wall (B). Pinching, on the contrary, causes very poorly vertically-aligned textures or nonaligned textures $(\mathrm{C})$ (R. Thér). 
Europe. We have demonstrated that the introduction of pottery, formed using a potter's wheel, at the beginning of the La Tène period represents a clear technological discontinuity in terms of ceramic paste preparation, the entire forming sequence and the firing procedure. The identified forming sequence (wheel shaping) is a time-consuming and skill-demanding activity. The clear technological divergence between wheelmade pottery and the rest of pottery production reflects a divergence of identities within the potting community. The results can be interpreted as being the consequences of the transmission of a novel technology in a restricted learning network. In contrast, during the La Tène C-D1 period, wheel-made pottery was produced in a number of local pottery workshops. A diverse use of rotational energy has been identified. Wheel throwing occurred as common practice in forming fine ware along with the use of wheel shaping. The diversification of the use of a potter's wheel can be linked to changes in the selective environment caused by increased socio-economic complexity in the period. The results suggest the existence of independent specialists sensitive to cost-effective production techniques (Thér and Mangel, 2014; Thér, Mangel and Gregor, 2014; 2015; 2017; Thér, Mangel and Toms, 2015).

Less successful was the application of the methodology to hand-building forming techniques. We compared two basic families of hand-building techniques (coiling and slab-building). The results show that orientation analysis can differentiate between the orientation caused by the forming force used in shaping the slabs and coils. However, the pottery-forming practice cannot be simplified to these basic forming forces. Incorporation of slabs or coils into the vessel wall or different approaches to form the segments might result in significant transformation of the initial or ideal orientation, resulting in an overlap of orientation characteristics between the variants of the two basic forming families. We demonstrated that the described methodology can be used to trace basic trends in the development of pottery-forming techniques in the Early Neolithic settlement in Bylany. However, the results of our experimental analysis should be a warning against too schematic a view of the orientation patterns reflecting these basic forming techniques. Slab building and coiling are among the techniques where the vectors of the forming force are not sufficiently constrained by the principles of the technique. Consequently, they can produce highly variable orientations of the microstructure of the formed ceramic vessels (Thér, Květina and Neumannová, 2019).

\section{Journals}

The extensive experimental research resulted in the founding of the journal Reconstruction and Experiment in Archaeology. The original aim of the journal was to support the development of archaeological experimentation in the Czech Republic and to create a platform for the publication of experimental research. However, it soon became apparent that the Czech environment is too small to fill out such a specialised journal. In 2004, the journal was divided into two separate series. The international format of the journal under the name EuroREA (now EXARC journal http:// journal.exarc.net/ published by EXARC http://exarc.net/) has extended its geographical scope. The focus of the Czech journal, with the title supplemented by Živá archeologie (Living Archaeology), was extended. The journal is still oriented towards archaeological experiment and reconstruction, but also welcomes articles dealing with the interpretation of archaeological evidence and presentation of archaeological knowledge.

\section{Applied informatics}

The third field of interdisciplinary endeavour at the Department of Archaeology FF UHK is applied informatics. The first project was focused on the use of geographic information systems for the electronic publication of documentation from archaeological excavations. In the first application, the data from a large-scale excavation of the Neolithic settlement in Mohelnice was used. The aim of the project was to create a comprehensive means of excavation data publication and offer new possibilities for spatial analysis (Thér, 2004; 2008). The project was built on the ArcGIS software platform and ArcGIS became the basis for the processing of archaeological documentation at the Department of Archaeology FF UHK. Since then, the activities related to applied informatics have expanded and at present also include the application of $3 \mathrm{D}$ modelling and virtual reality. This development resulted in the accreditation of a bachelor's study program "Computer support in archaeology" in 2006.

Most recently, a project focused on the automated documentation and classification of pottery is being developed and overseen by J. Wilczek. With the use of the latest developments in mathematics, biology, physics, informatics and archaeology, an easy-to-use computer application for creating illustrations, classifications, and automatic searches is being developed in cooperation with the Universite de Bourgogne Franche-Comté in Dijon (France). The aim of the computer application is the implementation of a number of approaches allowing automatic classification and automatic recognition of whole vessel shapes based on their fragments. These approaches will include both previously published, but as yet unused, methods (ICP, SIFT, etc.), and new approaches based on modern statistical methods and geometric morphometry. In this respect, the use of a number of Machine Learning methods is also very promising, allowing the combination of quantitative statistical methods and the intuitive qualities of ceramics specialists (Figure 7; Wilczek, 2017; Wilczek et al., 2018). Applying these methods should increase the quality and quantity of archaeological data used in archaeological interpretation.

The other project integrates approaches for the identification of technological phenomena in archaeological 


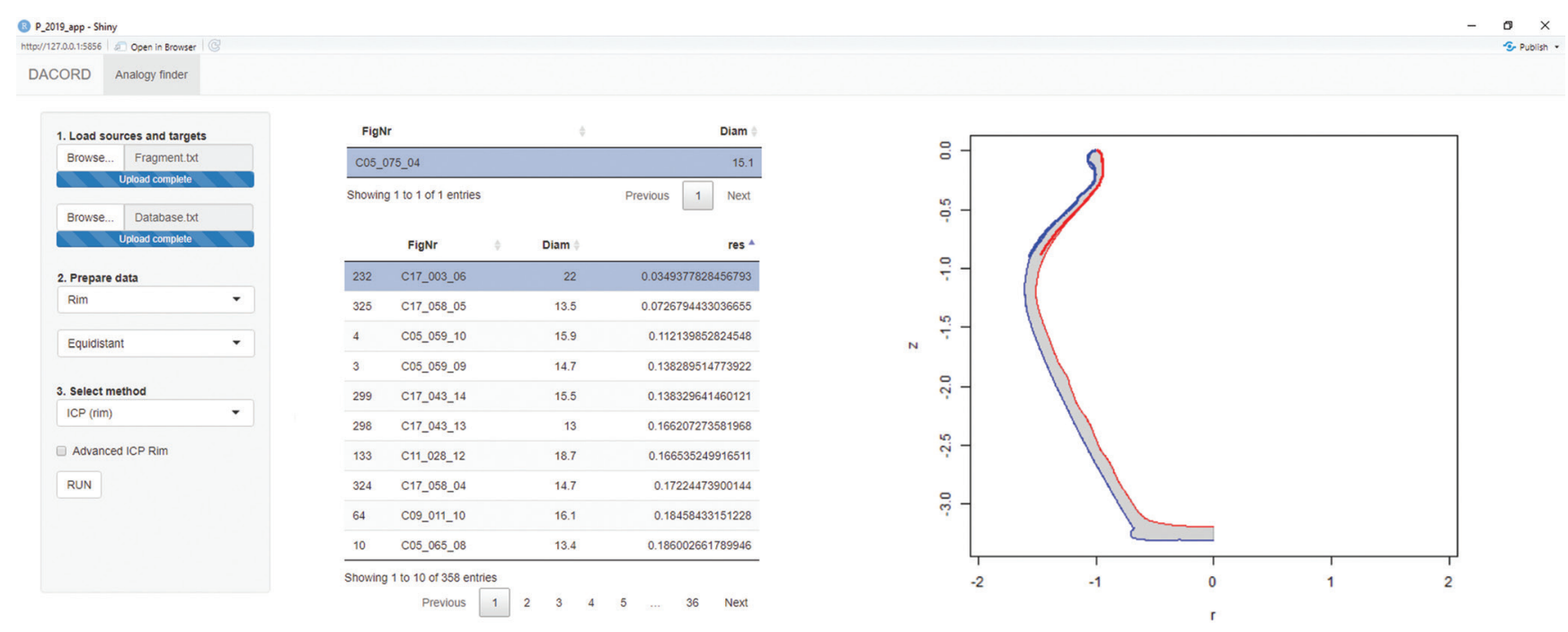

Figure 7. Prototype of the computer application allowing morphological analogy identification to a fragment's profile. Example of a result - the most similar complete vessel (C17_003_06; grey polygon shown by red and blue thin outlines) has been identified as the best analogy to a selected fragment (C05_075_04; red and blue thick outlines) within the database containing 358 complete vessels (J. Wilczek).

pottery with methods of semi-automated classification. The main objective of the project is to propose solutions allowing to semi-automatically highlight, quantify and interpret diagnostic traces on the surface of archaeological pottery. The developed procedures apply some quantitative analyses of $3 \mathrm{D}$ pottery models. In addition, the project also explores the automatic determination of a manufacturing sequence in order to increase the effectiveness of the archaeological analyses and interpretation of archaeological pottery. The project will also explore the possibilities of the effective sharing of analysed, annotated, and interpreted 3D pottery models with the wider scientific community.

\section{Conclusion}

Thus it has been the long-term focus on interdisciplinary research within the Department of Archaeology that has led to the decision to share responsibility for the publishing and provision of financial and organisational support for the further development of the IANSA journal. The Philosophical Faculty of the University of Hradec Králové has been a copublisher of the IANSA journal since the issue 2/2018.

\section{References}

MANGEL, T. and THÉR, R., 2014. Pyrotechnologická zařízení z období HA D2-3 až LT A z Kapsovy Lhoty (okr. Strakonice). K možnostem interpretace fragmentárních nálezů pyrotechnologických zařízení s rošty. In: J. Čižmářová, N. Venclová and G. Březinová, eds. Moravské křižovatky. Středni Podunaji mezi pravěkem a historii. Brno: Moravské zemské muzeum. pp. 801-813.

MANGEL, T. and THÉR, R., 2018. Laténské hrnčiřské pece ve střední Evropě. Červený Kostelec: Nakladatelství Pavel Mervart.

MANGEL, T., THÉR, R., and GREGOR, M., 2015. K otázce hrnčířských vypalovacích zařizení s rošty z období Ha C - LT A ve střední Evropě
Archeologické rozhledy, 67, 356-399.

THÉR, R., 2004. Elektronická dokumentace výzkumu Mohelnice. In: M. Lutovský, ed. Otázky neolitu a eneolitu 2003. Praha: Ústav archeologické památkové péče středních Čech. pp. 425-431.

THÉR, R., 2008. Využití GIS pro zpracování a publikaci plošných archeologických výzkumů: př́íklad neolitického sídliště v Mohelnici u Zábřeha. In: J. Macháček, ed. Počitačová podpora v archeologii 2. Brno, Praha, Plzeň: Ústav archeologie a muzeologie, Masarykova univerzita, Archeologický ústav AV ČR, Katedra archeologie, Západočeská univerzita v Plzni, pp. 93-102.

THÉR, R., 2014. Identification of pottery firing structures using the thermal characteristics of firing. Archaeometry, 56, 78-99.

THÉR, R., 2016. Identification of pottery-forming techniques using quantitative analysis of the orientation of inclusions and voids in thin sections. Archaeometry, 58(2), 222-238.

THÉR, R., KALLISTOVÁ, A., SVOBODA, Z., KVĚTINA, P., LISÁ, L., BURGERT, P., and BAJER, A., 2018. How Was Neolithic Pottery Fired? An Exploration of the Effects of Firing Dynamics on Ceramic Products. Journal of Archaeological Method and Theory [online].

THÉR, R., KVĚTINA, P., and NEUMANNOVÁ, K., 2019. Coiling or slab building: Potential of orientation analysis for identification of forming techniques used by Early Neolithic potters. Journal of Archaeological Science: Reports, 26, 1-14.

THÉR, R. and MANGEL, T., 2014. Inovace a specializace v hrnčířském remesle $\mathrm{v}$ době laténské: model vývoje organizačních forem výroby. Archeologické rozhledy, 66(1), 3-39.

THÉR, R., MANGEL, T., and GREGOR, M., 2014. Produkce laténských hrnčirrských pecí na Chrudimsku: příspěvek k poznání organizace hrnčířského řemesla. Archeologické rozhledy, 66(3), 415-452.

THÉR, R., MANGEL, T., and GREGOR, M., 2015. Život hrnčiře začiná v LT A. Výroba keramiky $v$ době laténské na Chrudimsku. Hradec Králové: Filozofická fakulta UHK.

THÉR, R., MANGEL, T., and GREGOR, M., 2017. Potter's wheel in the Iron Age in Central Europe: process or product innovation? Journal of Archaeological Method and Theory. 1-44.

THÉR, R., MANGEL, T., and TOMS, P., 2015. Potter's wheel and organization of pottery production in the Late Iron Age in Central Europe: a case study from Eastern Bohemia. In: A. Danielisová and M. FernandezGötz, eds. Persistent economic ways of living: production, distribution, and consumption in the Iron Age and Early Medieval Period. Budapest: Archeolingua, pp. 185-202.

THÉR, R. and TICHÝ, R., 2000. Centrum experimentální archeologie Všestary. Rekonstrukce a experiment $v$ archeologii, 1, 164-169. 
THÉR, R. and TICHÝ, R., 2002. The Structure of the Centre of Experimental Archaeology Všestary. Experimentelle Archäologie in Europa. Bilanz, 1 $181-187$.

THÉR, R. and TOMS, P., 2016. Quantification of the orientation and alignment of aplastic components of a ceramic body as a method for distinguishing among various means of using a rotational device in pottery forming. Journal of Archaeological Science: Reports, 9, 33-43.

TICHÝ, R., ed., 1999. Monoxylon II: plavba po 8000 letech, dobrodružství experimentální archeologie. Náchod: JB Production.

TICHÝ, R., 2000a. Projekt "Borek". Př́íspěvek ke stavbě a funkci neolitického obytného areálu. Rekonstrukce a experiment $v$ archeologii, 1, 71-116.

TICHÝ, R., 2000b. Expedice Monoxylon II. Dlabaný člun v neolitu západního Středomoří. Rekonstrukce a experiment $v$ archeologii, 1, 37-70.

TICHÝ, R., 2001a. Archeologizace na neolitických sídlištích. Rekonstrukce a experiment $v$ archeologii, 2(1), 85-100.

TICHÝ, R., 2001b. Expedice Monoxylon: pocházíme z mladši doby kamenné. Hradec Králové: Společnost experimentální archeologie.

TICHÝ, R., 2001c. Expedice Monoxylon I. Dlabaný člun v Egejském moři. Rekonstrukce a experiment $v$ archeologii, 2, 21-44.
TICHÝ, R., 2003. Dlabané čluny. Příspěvek experimentální archeologie k poznání vnitrozemské plavby. Rekonstrukce a experiment $v$ archeologii, 3, 40-71.

TICHÝ, R., 2016. The Earliest Maritime Voyaging in the Mediterranean: View from Sea. Rekonstrukce a experiment $v$ archeologii (Živá archeologie), 18, 26-36.

TICHÝ, R., 2017. "Days of Living Archaeology" at the Prehistoric Archaeopark Všestary, Czech Republic. EXARC Journal [online]. (2). Available from: https://exarc.net/issue-2017-2/aoam/days-livingarchaeology-prehistoric-archaeopark-vsestary-czech-republic.

WILCZEK, J., 2017. Morphometrics of (especially ceramic) Celtic artefacts - new methods of acquisition, systematization and valorization of the past. In: J. Wilczek, A. Cannot, T. Le Cozanet and J. Remy, eds. Interdisciplinarité et nouvelles approches dans les recherches sur l'âge du Fer. Interdisciplinarity and New Approaches in the Research of the Iron Age. International Doctoral Conference 2015. Bibracte (France), 2015. Brno: Masarykova univerzita, pp. 73-76.

WILCZEK, J., MONNA, F., JÉBRANE, A., CHAZAL, C.L., NAVARRO, N., COUETTE, S., and SMITH, C.C., 2018. Computer-Assisted Orientation and Drawing of Archaeological Pottery. Journal on Computing and Cultural Heritage, 11(4), 22:1-22:17. 